\begin{tabular}{|c|c|c|}
\hline $\begin{array}{l}\text { EXCELLENT } \\
\text { PUBLISHERS }\end{array}$ & $\begin{array}{c}\text { International Journal of Current Research } \\
\text { and Academic Review } \\
\text { ISSN: 2347-3215 (Online):,; Volume } 5 \text { :,; Number } 10 \text { (October-2017) } \\
\text { Journal homepage: http://www.ijcrar.com }\end{array}$ & $=$ \\
\hline
\end{tabular}

doi: https://doi.org/10.20546/ijcrar.2017.510.004

\title{
Effect of Spent Engine Oil in Soil on the Root Elongation and Seedling Evaluation of Three Local Pepper Species, Capsicum frutescens, Capsicum chinense and Capsicum annum
}

\author{
Obazuaye O. Donald ${ }^{1}$, Obueh O. Henrietta ${ }^{1^{*}}$ and Ikuvbogie Francis ${ }^{2}$ \\ ${ }^{1}$ Department of Biology, College of Education, P.M.B 1144, Ekiadolor, Benin City, Edo State, Nigeria \\ ${ }^{2}$ Department of Science Laboratory Technology, Edo State Polytechnic, Usen, Edo State, Nigeria
}

*Corresponding author

\section{Abstract}

The effect of spent engine oil on the root elongation and seedling evaluation of three species of pepper (Capsicum frutescens, Capsicum chinense and capsicum annum) was studied. There was increase in root elongation with $1 \%$ oil pollution concentration for $C$. frutescens and $C$. chinense while there was reduction in root elongation of $C$. annum due to delay in germination. Control of $C$. frutescens plant had mean root length of $4.667 \pm 0.088 \mathrm{~cm}$ while $1 \%$ treated soil had $5.267 \pm 0.145 \mathrm{~cm}$. The control of $C$. chinense plant and $1 \%$ treated soil had mean root lengths of $4.467 \pm 0.186 \mathrm{~cm}$ and $5.067 \pm 0.120 \mathrm{~cm}$ respectively. C. annum control and $1 \%$ treatment plants had the mean root length of $4.365 \pm 0.100 \mathrm{~cm}$ and $2.767 \pm 0.145 \mathrm{~cm}$ respectively. The germination, growth and root elongation of the three pepper species were inhibited by the treatments of $3 \%, 6 \%$ and $9 \%$ concentration. There is significance difference ( $\mathrm{P}$ $<0.05$ ) between the root elongations of treatment among $C$. frutescens, $C$. chinense and $C$. annum. Normal seedlings were observed for control plants of $C$. frutescens, $C$. chinense and C. annum but the $1 \%$ treatment plants had defect in the order of $C$. annum $<$ C. chinense $<$ C. frutescens.
\end{abstract}

\section{Article Info}

Accepted: 12 September 2017

Available Online: 20 October 2017

\author{
Keywords \\ Capsicum annum, \\ Capsicum chinense, \\ Capsicum frutescens, \\ Root elongation, \\ Seedling evaluation, \\ Soil, \\ Spent engine oil.
}

\section{Introduction}

The disposal of spent engine oil into gutters, water drains, open vacant plots and farms is a common practice in Nigeria especially by motor mechanics. This oil also called spent lubricant or waste engine oil is usually obtained after servicing and subsequently draining from automobile and generator engines. Pollution from waste engine oil has been reported to be more widespread than that of crude oil (Odjegba and Sadiq, 2002). Atuanya (1987) reported that waste oil contamination of soil resulted in the soil remaining unsuitable for crop growth and depending on the degree of contamination, type of soil and soil environment. The soil may remain unsuitable for crop growth for months or years until the oil is degraded to tolerable level and the stabilization recorded for $\mathrm{pH}$ may be due to degradation through time. Adenipekun and Kassin (2006) observed that used engine oil affected plant height, stem, girth, moisture content, leaf area of leaves in Celosia argentea. Spent lubricant contains metals that could cause unsatisfactory growth in plants, insufficient aeration of the plants, chlorosis of the leaves and dehydration of plants (Dejong, 1980). Also, the presence of petroleum 
hydrocarbons in the waste engine oil adversely affects the germination and growth of plants in soils (Samina and Adams, 2002). There is insufficient aeration due to a decrease in air-filled pore spaces in the soil and an ensuring increase demand for oxygen caused by oildecomposing microorganisms (Gudin and Syratt, 1975).

Pepper (Capsicum spp) is a member of the solanaceae family that includes tomatoes, potato, tobacoo and petunia. It is one of the most important vegetables in Nigeria and it is widely grown in Nigeria. The main shoot is branched erect, postrate, freshly, often woody at the base, round or slightly angular.

The leaves are variable in size, simple broadly lenceolate to ovate, margina entire and tips pointed (Remison, 2005). The flowers are carried singly and are considered vegetables but are berries botanically (Norman et al., 1992).

Chile types are usually classified by fruit characteristics i.e pungency, colour, shape, flavour, size and their use, despite their vast differences, most Chile cultivars commercially cultivated in the world belong to the species, Capsicum annum, Capsicum frutescens and Capsicum chinense (Walsh and Hoot, 2001). They prefer a fertile loam soil with a high level of organic material reserves of essential elements. Good drainage is important since water logging is likely to cause leaf shedding.

Those commercially cultivated include Capsicum frutescens, $C$. annum and $C$. chinense. Anoliefo and Vwioko (1995) reported that the treatment of soil with $4 \%$ and $6 \%$ spent oil conveniently inhibited germination of Capsicum annum. They found out that mean height of leaf area of $C$. annum in soil treated with $3 \%$ spent oil gave very low values. Soils contaminated by spent oil inhibited the growth of Capsicum sp.

The pepper plant is of great importance. It is used in soups and stew and eaten raw in salads. The fruit of most species of Capsicum sp contains capsaicin which is a lipophilic chemical that can produce burning sensation in the mouth of unaccustomed eaters. Capsaicin is used in modern medicine as a circulatory stimulant and pain reliever. Aerosol extract of capsaicin usually known as pepper spray are used by the police as non-lethal means of incapacitating a person. The objective of this study is to investigate effect of waste engine oil pollution in soil on the root elongation and seedling growth of Capsicum frutescens, $C$. chinense and $C$. annum.

\section{Materials and Methods}

\section{Plant materials}

The plant materials used in this study were Capsicum frutescens, Capsicum chinense and Capsicum annum. The seeds were obtained from New Benin market in Benin City, Edo State, Nigeria and in one purchase; enough seeds were gotten for the study.

\section{Spent lubricating oil}

Waste engine oil was obtained from petrol engine vehicles after servicing of the vehicles that were five years and above. The waste engine oil was collected from different mechanic workshops at Isihor - Oluku, Benin City and poured together as one waste engine oil.

\section{Seed viability test}

The seeds were put in bowls of water and left for 20 minutes. Submerged seeds were collected and used while the ones that remained afloat were discarded. Viable seeds of Capsicum frutescens, Capsicum chinense and Capsicum annum were sown in soils supplied with water (control) and spent lubricating oil at different strengths.

\section{Soil treatment}

The soil samples were treated with $1 \%, 3 \%, 6 \%$ and $9 \%$ concentration $(\mathrm{w} / \mathrm{w})$ of spent lubricating oil or water (control) before planting in polyethylene bags $(12 \mathrm{~cm}$ by $25 \mathrm{~cm})$. The treatment of soil with waste oil was carried out in small amount at a time until thoroughly mixed. The polyethylene bags containing the sown seeds were left in the nursery for germination and later transferred to the field. The seeds were sown to an appropriate depth of $3 \mathrm{~cm}$ in the polyethylene bags. Twenty seeds were planted per bag for the three experimental plants.

\section{Root elongation}

Seedlings were examined from replicates on a two-day interval and readings were taken of the length of the main axis. Examined seedlings were disposed off after measurement.

\section{Seedling evaluation}

This was done on the 10th day after germination and was examined for normal seedlings, seedlings with slight defects and seedlings with secondary infection. 


\section{Data analysis}

The data were analyzed using one way analysis of variance and the significant means separated with the Duncan's multiple range tests (Ogbeibu, 2005).

\section{Results and Discussion}

The root elongation of the seedlings for $C$. frutescens, $C$. chinense and $C$. annum after treatment with the spent lubricating oil are presented in Tables 1, 2 and 3. There was increase in root elongation with $1 \%$ oil pollution concentration for $C$. frutescens and $C$. chinense while there was reduction in root elongation for $C$. annum due delay in germination. Control of $C$. frutescens plant had length of $4.667 \pm 0.088 \mathrm{~cm}$ while $1 \%$ oil treated soil had $5.267 \pm 0.145 \mathrm{~cm}$. The control of $C$. chinense plant and $1 \%$ oil treated soil had root lengths of $4.467 \pm 0.186 \mathrm{~cm}$ and $5.067 \pm 0.120 \mathrm{~cm}$ respectively. $C$. annum control and $1 \%$ oil treated plants had the root length of $4.365 \pm 0.100$ $\mathrm{cm}$ and $2.767 \pm 0.145 \mathrm{~cm}$ respectively. There is significance difference $(\mathrm{P}<0.05)$ between the root elongation in soil treated with waste engine oil among $C$. frutescens, $C$. chinense and $C$. annum. There was no root elongation growth at all during the days of germination for plants in 3\%, 6\% and 9\% oil polluted soils. According to Anoliefo and Uwioko (1995), treatment of soil with $4 \%$ and $5 \%$ spent oil consistently inhibited germination of pepper (Capsicum annum) and tomato (Lycopersicom esculentum) with more adverse effect on tomato. This could be due to the herbicidal and phototoxic properties of spent engine oil to organisms (Vwioko and Fashemi, 2005). Terge (1984) reported that germination and growth of different species of vascular plants were inhibited by toxic concentration of compounds in the soil leading to killing of the seeds. Growth, development and yield of plants may be accelerated, impaired or prevented before the oil polluted soils become suitable for growth of plants for a long time until it is degraded to a tolerable level (Udo and Opera, 1984). Figure 1 shows the seedlings of $C$. frutescens $\left(\mathrm{V}_{\mathrm{A}}\right)$, C. chinense $\left(\mathrm{V}_{\mathrm{B}}\right)$ and $C$. annum $\left(\mathrm{V}_{\mathrm{C}}\right)$ obtained after 10days of germination for control and $1 \%$ in spent engine oil treated soils.

Table.1 Effect of spent lubricating oil on the seedling root elongation of $C$. frutescens

\begin{tabular}{ccccccc}
\hline Treatment $(\%)$ & \multicolumn{5}{c}{ Time in days / Seedling Root Elongation $(\mathbf{c m})$} \\
\cline { 2 - 6 } & $\mathbf{2}$ & $\mathbf{4}$ & $\mathbf{6}$ & $\mathbf{8}$ & $\mathbf{1 0}$ \\
\hline $\mathbf{0}$ & $\mathbf{0 . 5 0 0} \pm$ & $\mathbf{0 . 1 1 5}$ & $\mathbf{1 . 4 0 0 \pm 0 . 1 1 5}$ & $\mathbf{2 . 5 6 7 \pm 0 . 1 4 5}$ & $\mathbf{3 . 8 0 0 \pm 1 . 5 2 7}$ & $\mathbf{4 . 6 6 7 \pm 0 . 0 8 8}$ \\
$\mathbf{1}$ & $\mathbf{0 . 5 6 7 \pm}$ & $\mathbf{0 . 0 8 8}$ & $\mathbf{1 . 9 6 7 \pm 0 . 1 4 5}$ & $\mathbf{3 . 0 0 0} \pm \mathbf{0 . 1 7 3}$ & $\mathbf{4 . 1 6 7 \pm 0 . 1 2 0}$ & $\mathbf{5 . 2 6 7 \pm 0 . 1 4 5}$ \\
$\mathbf{6}$ & - & - & - & - & - \\
$\mathbf{9}$ & - & - & - & - & - \\
\hline
\end{tabular}

$--=$ no growth

Table.2 Effect of spent lubricating oil on the seedling root elongation of C. chinense

\begin{tabular}{cccccc}
\hline Treatment $(\%)$ & \multicolumn{5}{c}{ Time in days / Seedling Root Elongation $(\mathbf{c m})$} \\
\cline { 2 - 6 } & $\mathbf{2}$ & $\mathbf{4}$ & $\mathbf{6}$ & $\mathbf{8}$ & $\mathbf{1 0}$ \\
\hline $\mathbf{0}$ & $\mathbf{0 . 3 6 7 \pm 0 . 0 8 4}$ & $\mathbf{1 . 3 0 0} \pm \mathbf{0 . 1 5 3}$ & $\mathbf{2 . 7 3 3} \pm \mathbf{0 . 1 2 0}$ & $\mathbf{3 . 6 0 0} \pm \mathbf{0 . 1 5 0}$ & $\mathbf{4 . 4 6 7 \pm 0 . 1 8 6}$ \\
$\mathbf{3}$ & $\mathbf{0 . 5 1 0} \pm \mathbf{0 . 1 1 0}$ & $\mathbf{1 . 9 0 0 \pm 0 . 1 5 2}$ & $\mathbf{3 . 0 6 7 \pm 0 . 1 7 6}$ & $\mathbf{4 . 1 0 0} \pm \mathbf{0 . 1 5 3}$ & $\mathbf{5 . 0 6 7 \pm 0 . 1 2 0}$ \\
$\mathbf{6}$ & - & - & - & - & - \\
$\mathbf{9}$ & - & - & - & - & - \\
\hline
\end{tabular}

-- = no growth

Table.3 Effect of spent lubricating oil on the root elongation $(\mathrm{cm})$ of C. annum

\begin{tabular}{cccccc}
\hline Treatment $(\%)$ & \multicolumn{5}{c}{ Time in Days / Seedling Root Elongation $(\mathbf{c m})$} \\
\cline { 2 - 6 } & $\mathbf{2}$ & $\mathbf{4}$ & $\mathbf{6}$ & $\mathbf{8}$ & $\mathbf{1 0}$ \\
\hline $\mathbf{0}$ & $\mathbf{0 . 2 6 7 \pm 0 . 0 5 8}$ & $\mathbf{1 . 5 3 3} \pm \mathbf{0 . 1 7 6}$ & $\mathbf{2 . 6 3 3} \pm \mathbf{0 . 0 8 8}$ & $\mathbf{4 . 0 0 0 \pm 0 . 1 1 5}$ & $\mathbf{4 . 3 6 5 \pm 0 . 1 0 0}$ \\
$\mathbf{3}$ & $\mathbf{0 . 0 0 0 \pm 0 . 0 0 0}$ & $\mathbf{0 . 3 0 0 \pm 0 . 0 0 8}$ & $\mathbf{1 . 0 3 3} \pm \mathbf{0 . 0 8 8}$ & $\mathbf{1 . 7 6 7 \pm 0 . 0 8 8}$ & $\mathbf{2 . 7 6 7 \pm 0 . 1 4 5}$ \\
$\mathbf{6}$ & - & - & - & - & - \\
$\mathbf{9}$ & - & - & - & - & - \\
\hline
\end{tabular}

- = no growth 
Table.4 Evaluation of $C$. frutescens seedling grown in soil treated with water (control) and spent lubricating oil

\begin{tabular}{|c|c|c|c|}
\hline $\begin{array}{c}\text { Oil } \\
\text { Treatment } \\
(\%)\end{array}$ & $\begin{array}{c}\text { Percentage Germination Rate } \\
(\%)\end{array}$ & Features & Remarks \\
\hline 0 & 66.70 & $\begin{array}{l}\text { The germinated seeds developed into } \\
\text { normal seedlings characterized by long and } \\
\text { slender primary root covered with numerous } \\
\text { root hairs and ending in a fine tip, straight } \\
\text { more or less slender and elongated } \\
\text { hypocotyls. }\end{array}$ & $\begin{array}{l}\text { Intact } \\
\text { Seedlings }\end{array}$ \\
\hline 1 & 28.80 & $\begin{array}{l}\text { All germinated seeds developed into normal } \\
\text { seedlings characterized by long slender } \\
\text { primary root (slightly longer than the } \\
\text { control) without hairs and ending in fairly } \\
\text { fine tip straight more or less slender and } \\
\text { elongated hypocotyls. }\end{array}$ & $\begin{array}{l}\text { Seedlings } \\
\text { with slight } \\
\text { defects }\end{array}$ \\
\hline $3,6,9$ & - & - & 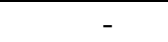 \\
\hline
\end{tabular}

- = no growth

Table.5 Evaluation of $C$. chinense seedling grown in soil treated with water (Control) and spent lubricating oil

\begin{tabular}{|c|c|l|l|}
\hline $\begin{array}{c}\text { Oil } \\
\text { Treatment } \\
(\mathbf{\%})\end{array}$ & $\begin{array}{c}\text { Percentage Germination Rate } \\
(\%)\end{array}$ & \multicolumn{1}{|c|}{ Features } & \multicolumn{1}{|c|}{} \\
\hline $\mathbf{0}$ & 62.20 & $\begin{array}{l}\text { Germinated seeds developed into normal } \\
\text { seedlings characterized by long and slender } \\
\text { primary root hairs and ending in a fine tip, } \\
\text { straight more or less slender and elongated } \\
\text { hypocotyls. }\end{array}$ & Seedlings \\
\hline $\mathbf{1}$ & 23.30 & $\begin{array}{l}\text { Germinated seeds developed into normal } \\
\text { seedlings characterized by long and slender } \\
\text { primary root (slightly longer than control) } \\
\text { with root hairs and ending more or less } \\
\text { slender and elongated hypocotyls. }\end{array}$ & $\begin{array}{l}\text { Seedling } \\
\text { defects }\end{array}$ \\
\hline $\mathbf{3 , 6 , 9}$ & & \multicolumn{1}{|c}{-} & - \\
\hline
\end{tabular}

$-=$ no growth

Table.6 Evaluation of C. annum seedling grown in soil treated with water (Control) and spent lubricating oil

\begin{tabular}{|c|c|l|l|}
\hline $\begin{array}{c}\text { Oil } \\
\text { Treatment } \\
(\mathbf{\%})\end{array}$ & $\begin{array}{c}\text { Percentage Germination Rate } \\
\mathbf{( \% )}\end{array}$ & \multicolumn{1}{|c|}{ Features } & \multicolumn{1}{|c|}{ Remarks } \\
\hline $\mathbf{0}$ & 55.00 & $\begin{array}{l}\text { Germinated seeds developed into normal } \\
\text { seedlings characterized by long and slender } \\
\text { primary root, covered with numerous root } \\
\text { hairs and ending in fine tip straight more or } \\
\text { less slender and elongated hypocotyls. }\end{array}$ & $\begin{array}{l}\text { Intact } \\
\text { Seedlings }\end{array}$ \\
\hline $\mathbf{1}$ & 17.70 & $\begin{array}{l}\text { About half of the germinated seeds showed } \\
\text { defects. Primary root was slightly retarded } \\
\text { (compared to the control), twisted, long and } \\
\text { slender with root hairs and ends in a fairly } \\
\text { fine tip. }\end{array}$ & $\begin{array}{l}\text { Secondary } \\
\text { sefects }\end{array}$ \\
\hline $\mathbf{3 , 6 , 9}$ & - & - & - \\
\hline
\end{tabular}

- = no growth 
Fig.1 Seedlings of $C$. frutescens $\left(\mathrm{V}_{\mathrm{A}}\right)$, C. chinense $\left(\mathrm{V}_{\mathrm{B}}\right)$ and $C$. annum $\left(\mathrm{V}_{\mathrm{C}}\right)$ after 10 days of germination for control and $1 \%$ in spent engine oil treated soils

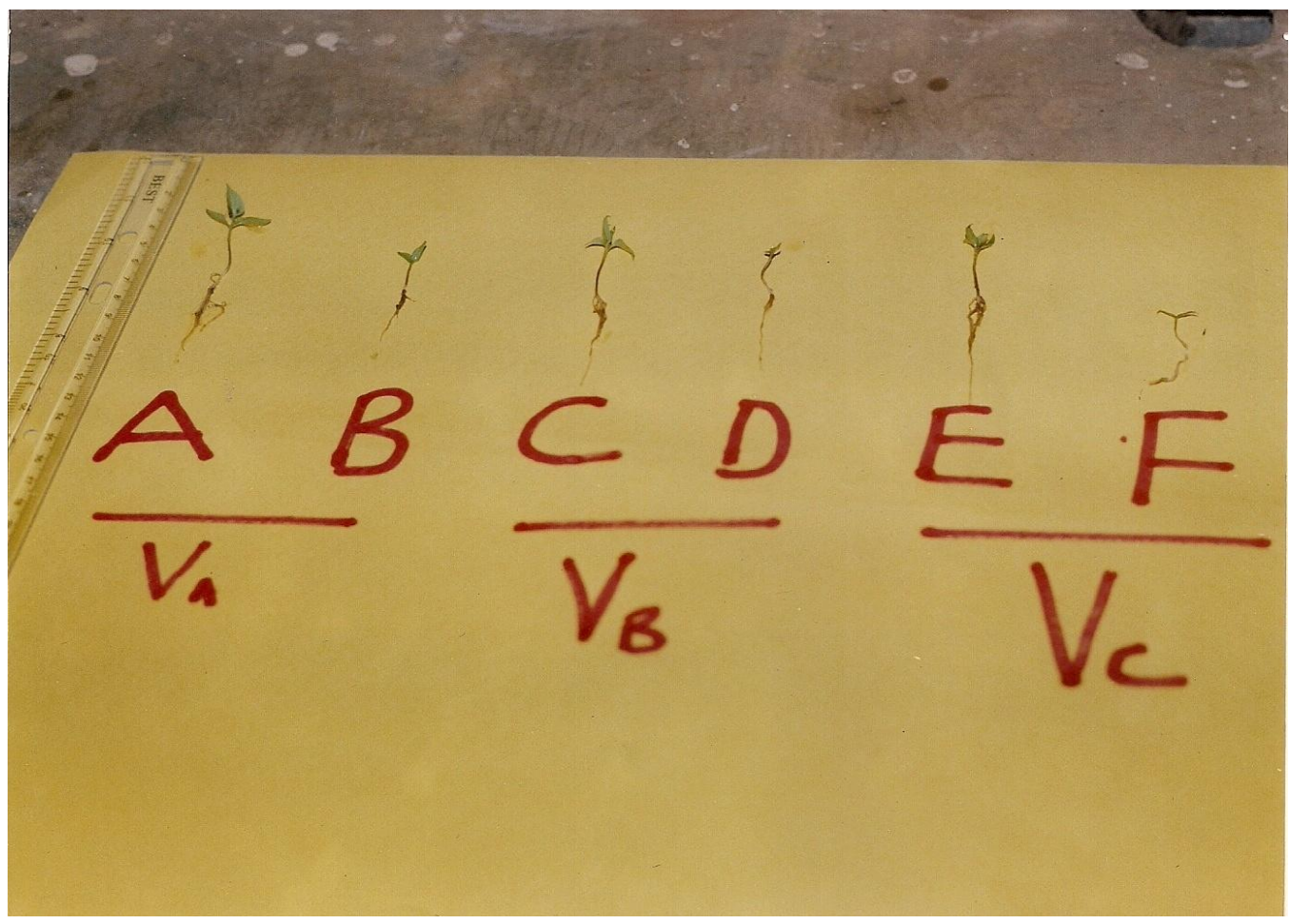

Tables 4, 5 and 6 show the seedling evaluation of the pepper species. The pepper species $C$. frutescens, $C$. chinense and $C$. annum showed normal seedling growth for the control plants while the seedlings grown in the $1 \%$ spent oil treated soil had various defects.. Evaluation of the seedlings showed defects such as twisted epicotyl, retarded growth, reduced number of root hairs, reduced root size and missing parts (Figure 1). Seedling evaluation is very important from the horticultural view as abnormal seedlings do not establish into healthy plants (Bekendem and Grob 1979). Gill et al., (1992) suggested that seedling ecology and evaluation may have considerable relevance to the selection of useful plants. From the findings of this study, C. frutescens had the greatest potential of survival while $C$ annum had the least potential of survival.

Spent engine oil pollution had effect on the pepper species as they grew with significant difference in root elongation and defects in root and seedling leading to the death of the plants before fruiting. Root is a site of water absorption in plants and helps to anchor the plant firmly to the soil. The reduction in the root hairs, slender primary root and twisted hypocotyl brings about a consequent reduction in surface area available for water absorption hence have adverse effect on root and seedling development. Thus, efforts should be made to enlighten all stakeholders on the need to properly dispose off used engine oil.

\section{References}

Adenikpekun, C. O. and Kassim, L.O. (2006). Effects of Spent Engine Oil on the growth and moisture of Colosia argenrtea. In: Botany and Environmental Health, Akpan, G. and Odoemena C.S.J. (Eds.). University of Uyo, Nigeria, pp: 108-111

Anoliefo, G.O and Vwioko, D.E (1995) Effects of spent lubricating oil on the growth of Capsicum annum and Lycopersicom esculentum Miller. Environmental Pollution 88: 361-364 - 46.

Atuanya, E. I (1987) Effect of waste engine oil on physical and chemical properties of soil. A case study of waste oil contaminated Delta soil in Bendel State. Nigerian Journal of Applied Science5:155176.

Bekendem, J and Grob R (1979). Handbook for seedling evaluation. ISTA Zurich Switzerland 130pp.

Dejong E. A (1980). The effect of crude oil spill on cereals. Environmental Pollution 22: 187 - 196

Gill, L.S., Nyawuame., H.G. K., Ehikhametalor A.O. (1992) Effect of crude oil on growth and anatomical 
features of Chromoleana, odorata L. Newsletter 6: $1-6$

Gudin, C and Syratt, W.J (1975) Biological aspects of land rehabilitation following hydrocarbon contamination. Environmental Pollution 8: 106 112.

Norman, D. M., Mason, J. R. and Clark. L. (1992). Capsaicin effects on consumption of food by cedar waxwings and house finches. The Wilson Journal of Ornithology 104: 549-551.YHUJI

Odjegba, V. and Sadiq, A. O. (2002). Effects of spent engine oil on the growth parameters, chlorophyll and protein levels of Amaranthus hybridus L. The Environmentalist 22, 23-28.

Ogbeibu A.E (2005) Biostatistics: A Practical Approach to Research and Data Handling. Mindex Publishing Co Ltd Benin City 264 pp.

Remison S. U. (2005). Arable and vegetable crops. Gift Press Association Publishers Benin City Nigeria. Pp. 28.

Samina, S and Adams, W. A (2002).The fate of diesel hydrogens in soil and their effect on the germination of perennial ryegrass. Environmental Toxicology 17: $49-62$.

Terge, K (1984) Effect of soil pollution on the germination and vegetative growth of five species of vascular plants. Oil and Petroleum Pollution Journal 2: $25-30$.

Udo, E. J. and Opara O. O. (1984). Some studies on the effects of crude oil pollution of soil on plant growth. J.Biol Chem., 11:26-29.

Vwioko, D. E and Fashemi, D. S (2005) Growth response of Ricinus communis L (castor oil) in spent lubricating oil polluted soil. Journal of Applied Sciences and Environmental Management 9(2):7379.

Walsh, B. M. and Hoot, S. B. (2001). Phytogenetic relationships of Capsicum (Solanaceae) using DNA sequences from two noncoding regions: the chloroplast atpB-rbcl spacer region and nuclear waxy introns. International Journal of Plant. Sciences 162: 1409-1418.

\section{How to cite this article:}

Obazuaye O. Donald, Obueh O. Henrietta and Ikuvbogie Francis. 2017. Effect of Spent Engine Oil in Soil on the Root Elongation and Seedling Evaluation of Three Local Pepper Species, Capsicum frutescens, Capsicum chinense and Capsicum annum. Int.J.Curr.Res.Aca.Rev. 5(10), 21-26.

doi: https://doi.org/10.20546/ijcrar.2017.510.004 